\title{
Phytochemicals in Food and Health
}

\author{
Dilip K. Rai
}

Citation: Rai, D.K. Phytochemicals in Food and Health. Foods 2021, 10, 901. https://doi.org/10.3390/ foods10040901

Received: 12 April 2021

Accepted: 17 April 2021

Published: 20 April 2021

Publisher's Note: MDPI stays neutral with regard to jurisdictional claims in published maps and institutional affiliations.

Copyright: (c) 2021 by the author Licensee MDPI, Basel, Switzerland. This article is an open access article distributed under the terms and conditions of the Creative Commons Attribution (CC BY) license (https:// creativecommons.org/licenses/by/ $4.0 /)$.
Department of Food BioSciences, Teagasc Food Research Centre Ashtown, D14K N3K Dublin, Ireland; dilip.rai@teagasc.ie

Consumption of plant-based diets, rich in phytochemicals, has been associated with reduced risk of degenerative diseases, improved overall health and well-being. However, assigning and identifying the food components, i.e., specific phytochemical and/or classes of phytochemicals, responsible for their biological activities are not adequately addressed. In addition, the impacts of thermal and emerging non-thermal food processing methods on the fate of phytochemicals are scarce. In this special issue, phytochemicals responsible for various biological activities have been investigated with advanced analytical techniques including liquid chromatography tandem mass spectrometry (LC-MS/MS), nuclear magnetic resonance (NMR) spectroscopy and molecular-docking experiments [1-5]. The impact of domestic thermal processing and non-thermal (high-pressure processing) on the phytochemicals has also been covered. Here, the roasting of broomcorn millet (Panicum miliaceum L.) significantly enhanced the antioxidant polyphenols, in particular ferulic acid, as opposed to steaming, puffing and extrusion [6]. High-pressure processing at $600 \mathrm{MPa}$ for $3 \mathrm{~min}$ of potatoes significantly reduced the polyphenol oxidase activity and the polyphenol responsible for potato browning, i.e., chlorogenic acid, without impacting antioxidant capacity as well as the cytotoxic glycoalkaloids ( $\alpha$-solanine and $\alpha$-chaconine) contents [5]. Caffeic acid derivatives, in particular salvianic acid A, from the leaves of Actinidia arguta (Hardy Kiwi) have been linked for anti-inflammatory properties [2]. Anti-inflammatory potency of commercial phytosterols, where $\beta$-sitosterols were more effective than stigmasterols and campesterol, has been established [7]. Triterpenoids in Minthosa diffusa play key role in the inhibition of cholinesterases - the enzymes associated with Alzheimer's and Parkinson's diseases, and may also contribute against diabetes [4]. On the other hand, individual or a category of polyphenols from different berries could not be clearly linked to various biological activities, suggesting the interplay of different polyphenols in promoting health, and therefore requires further studies [3,8].

Funding: This research received no external funding.

Conflicts of Interest: The authors declare no conflict of interest.

\section{References}

1. Petrásková, L.; Káňová, K.; Biedermann, D.; Křen, V.; Valentová, K. Simple and rapid hplc separation and quantification of flavonoid, flavonolignans, and 2,3-dehydroflavonolignans in silymarin. Foods 2020, 9, 116. [CrossRef] [PubMed]

2. Kim, G.-D.; Lee, J.Y.; Auh, J.-H. Metabolomic screening of anti-inflammatory compounds from the leaves of Actinidia arguta (Hardy Kiwi). Foods 2019, 8, 47. [CrossRef] [PubMed]

3. Koss-Mikołajczyk, I.; Kusznierewicz, B.; Bartoszek, A. The relationship between phytochemical composition and biological activities of differently pigmented varieties of berry fruits; comparison between embedded in food matrix and isolated anthocyanins. Foods 2019, 8, 646. [CrossRef] [PubMed]

4. Faraone, I.; Russo, D.; Chiummiento, L.; Fernandez, E.; Choudhary, A.; Monné, M.; Milella, L.; Rai, D.K. Phytochemicals of minthostachys diffusa epling and their health-promoting bioactivities. Foods 2020, 9, 144. [CrossRef] [PubMed]

5. Tsikrika, K.; O'Brien, N.; Rai, D.K. The effect of high pressure processing on polyphenol oxidase activity, phytochemicals and proximate composition of irish potato cultivars. Foods 2019, 8, 517. [CrossRef] [PubMed] 
6. Kalam Azad, M.O.; Jeong, D.I.; Adnan, M.; Salitxay, T.; Heo, J.W.; Naznin, M.T.; Lim, J.D.; Cho, D.H.; Park, B.J.; Park, C.H. Effect of different processing methods on the accumulation of the phenolic compounds and antioxidant profile of broomcorn millet (Panicum miliaceum L.) flour. Foods 2019, 8, 230. [CrossRef] [PubMed]

7. Yuan, L.; Zhang, F.; Shen, M.; Jia, S.; Xie, J. Phytosterols suppress phagocytosis and inhibit inflammatory mediators via erk pathway on lps-triggered inflammatory responses in raw264.7 macrophages and the correlation with their structure. Foods 2019, 8, 582. [CrossRef] [PubMed]

8. $\quad$ Eker, M.E.; Aaby, K.; Budic-Leto, I.; Rimac Brnčić, S.; El, S.N.; Karakaya, S.; Simsek, S.; Manach, C.; Wiczkowski, W.; de PascualTeresa, S. A review of factors affecting anthocyanin bioavailability: Possible implications for the inter-individual variability. Foods 2020, 9, 2. [CrossRef] [PubMed] 